\title{
CONTROL OF QUINIDINE DOSAGE
}

\author{
BY \\ H. E. ARCHER, DAVID WEITZMAN, AND HEDY L. KAY* \\ From St. Bartholomew's, The National Heart, and the West London Hospitals \\ Received May 3, 1955
}

The usefulness of quinidine in treatment of cardiac arrhythmias is often limited by the difficulty of determining adequate dosage. When control has not been effected by small doses, the physician may be deterred from increasing these because of the risk of toxicity. The electrocardiogram does not help to indicate that this may be imminent, since the effects of overdosage (widening of QRS and ventricular arrhythmias) are preceded by the clinical evidence of intolerance-vomiting and tinnitus.

In 1943 Brodie and Udenfriend described a fluorimetric method of estimating quinidine in serum. Subsequently it has been demonstrated that the therapeutic and toxic effects of the drug are related to serum concentration. Kalmanson and Sampson (1949) showed that toxic phenomena occurred more frequently with levels above $0.6 \mathrm{mg}$. $/ 100 \mathrm{ml}$. than with lower concentrations. Sokolow (1951) found that the majority of conversions from auricular fibrillation to sinus rhythm took place at levels between 0.4 and $1.0 \mathrm{mg}$. $/ 100 \mathrm{ml}$. Where such levels had not been reached, dosage could be increased with safety and with the possibility of therapeutic success. Above $1.0 \mathrm{mg}$. $/ 100 \mathrm{ml}$., the chances of conversion are only slightly enhanced, while the risk of toxicity is much increased.

In the present investigation, the relationships between dosage, serum level, and therapeutic effect were studied. The urinary excretion of quinidine was studied also, and the urines were tested with potassium mercuri-iodide (Tanret's reagent) to determine whether precipitate density was any guide to serum level. Tanret's reagent has been used hitherto to detect the presence of quinine in urine, either to ensure that prophylactic doses were actually being taken, or to determine whether quinine used therapeutically was being absorbed (see Howie and Murray-Lyon, 1943; and, for a quantitative method, Lipkin and Ramsden, 1918).

\section{MATERial AND Methods}

Seventeen patients were investigated. In thirteen there was auricular fibrillation, which was paroxysmal in four cases. One patient had persistent auricular flutter and there were three with paroxysmal tachycardia. Of the patients with fibrillation, one had essential hypertension and three had mitral valve disease; in one of these the arrhythmia first appeared after valvotomy. One case of paroxysmal tachycardia started following cardiac infarction. The case with flutter had an atrial septal defect and flutter became established after cardiac catheterization. In the remaining eleven there was no other evidence of cardiovascular disease. Quinidine sulphate was always given by mouth, usually at two-hourly intervals for between three and six doses daily. The total daily dose used ranged from 15 to 45 grains ( 1 to $3 \mathrm{~g}$.), but in addition studies were made in four patients after a single dose of 10 grains $(0.7 \mathrm{~g}$.). In each case, samples of blood and urine were obtained immediately preceding each dose of quinidine, and at intervals after the day's last dose, for a total period of 24 hours.

Estimation of Quinidine in Serum. To $39 \mathrm{ml}$. of distilled water $1 \mathrm{ml}$. of serum was added in * Working with a grant from the Dan Mason Research Foundation. 
a $100-\mathrm{ml}$. centrifuge tube, and mixed; $10 \mathrm{ml}$. of 20 per cent metaphosphoric acid were added with vigorous shaking to avoid occlusion of the quinidine by the protein precipitate, and allowed to stand for 15 minutes. The mixture was centrifuged at 2000 r.p.m. for 10 minutes and the clear supernatant liquid decanted. This solution is sufficiently acid to give maximum fluorescence. The fluorescence was then measured in the Hilger Spekker photoelectric fluorimeter, by comparison with the appropriate standard. A description of the instrument and technical procedure is given by Lothian (1942). A pair of Wood's glass filters were used to isolate the mercury line $365^{\circ} \mathrm{A}$. In front of the photocell on the left a neutral filter $\mathrm{H} 508$ was placed to block stray visible light from the photocell. A heat-absorbing filter was placed on the left of the lamp house. In front of the photocell on the right there was mounted a filter to absorb ultraviolet light that might be scattered in the solution.

The stock solution was quinidine sulphate $10 \mathrm{mg}$. in $100 \mathrm{ml}$. of $\mathrm{N} / 10$ sulphuric acid. From this, working standards of $0.1,0.05,0.025$, and $0.0125 \mathrm{mg}$. per $100 \mathrm{ml}$. were prepared by diluting the stock with 4 per cent metaphosphoric acid. When kept in a refrigerator the stock standard keeps indefinitely and the $0.1 \mathrm{mg}$. standard for several weeks. Weaker standards will keep for a few days. There is no difference in fluorescence between standards prepared with $N / 10$ sulphuric acid and 4 per cent metaphosphoric acid. Deproteinized filtrates from the serum of patients before administration of quinidine may be used for the preparation of standards, but such quinidine-free serum was not usually available. The highest concentration for which a linear relationship could be obtained was $0.2 \mathrm{mg}$. per $100 \mathrm{ml}$. The greatest accuracy was obtained when the standard used was $0.05 \mathrm{mg}$. per $100 \mathrm{ml}$. The test is compared with the appropriate standard and the ratio of the two fluorescence intensities determined. The conversion factor for quinidine sulphate to quinidine is 0.8287 .

We confirmed Edgar and Sokolow's (1950) findings that blood may be stored for several days without loss of quinidine. The protein-free filtrate retains its fluorescence for up to a fortnight.

Estimation of Quinidine in Urine. In a 50-ml. separating funnel $10 \mathrm{ml}$. of protein-free urine was placed and made alkaline with $1 \mathrm{ml}$. of $2 \cdot 5 \mathrm{~N} \mathrm{NaOH}$. The extraction was carried out with 15 plus 10 plus $10 \mathrm{ml}$. chloroform by shaking gently each time for one minute. Each chloroform extract was run into a second $50-\mathrm{ml}$. funnel and washed twice with $5 \mathrm{ml}$. of water which is then separated by aspiration. The same two portions of washing water were used for all extractions. The combined chloroform extracts were evaporated to dryness in a 100-ml. porcelain dish on a waterbath. The residue was dissolved in $100 \mathrm{ml} .4$ per cent metaphosphoric acid, using several portions and swirling the acid well all round the dish. The fluorimetric estimation is then carried out as for serum, diluting as necessary with 4 per cent metaphosphoric acid, using the same standards. Should the urine contain excess phosphate, preliminary removal with barium chloride is advisable. Recovery experiments showed complete recovery when quinidine sulphate was added to serum. With urine, the addition of quinidine sulphate to concentrations of between 5 and $80 \mathrm{mg}$. per $100 \mathrm{ml}$. resulted in recovery of from 95 to 101 per cent.

The Tanret Test. The reagent was prepared by dissolving $1.36 \mathrm{~g}$. of mercuric chloride in $70 \mathrm{ml}$. of water, and $5 \mathrm{~g}$. of potassium iodide in $20 \mathrm{ml}$. of water. The two were mixed and the volume made up with water to $100 \mathrm{ml}$. (Martindale, 1935). During mixing, an orange-red precipitate forms, which redissolves. The reagent turns yellow with the passage of time, from liberation of iodine, without affecting it for the purpose of this test. $5 \mathrm{ml}$. of clear urine (filtered if necessary) were placed in a test-tube and 5 drops of reagent added. This was found to ensure complete precipitation. The tube was shaken by inverting it a few times and the density of precipitate noted. The reagent as specified here is best for this test, since it produces a fine suspension. If the alternative formula with acetic acid be employed, coarsely granular precipitates are formed which settle too rapidly for interpretation. The precipitate density was recorded as " nil," " trace," " one plus " (an opacity through which print could be read) or "two plus" (a completely opaque tube).

Tanret's reagent is also precipitated by other alkaloids and by methonium salts and procaine amide; hence the test cannot be used in patients having these drugs. Other substances routinely used in cardiovascular disease were found not to be precipitated; these were digitalis, tromexan, 
dindevan, mercurial diuretics, penicillin, and sulphonamides. Their use concurrently with quinidine does not invalidate the test. Albumin gives a false positive, but the precipitate persists on heating, while that due to quinidine (or quinine) disappears, to return on cooling. Should albumin be present the urine must be heated with acetic acid and then filtered and cooled before adding Tanret's reagent.

\section{RESULTS}

After a single oral dose of 10 grains the highest serum level found was about $0.5 \mathrm{mg} . / 100 \mathrm{ml}$. (see Fig. 1). This peak was reached from two to four hours after ingestion, as found by Delevett and Poindexter (1946). With repeated doses, the level rose until a maximum was reached two hours after the last dose (Fig. 2), confirming the findings of Sokolow (1951). When dosage was continued for several months, the serum level remained round about a steady level throughout the

$$
\text { | } 10 \text { grains }
$$

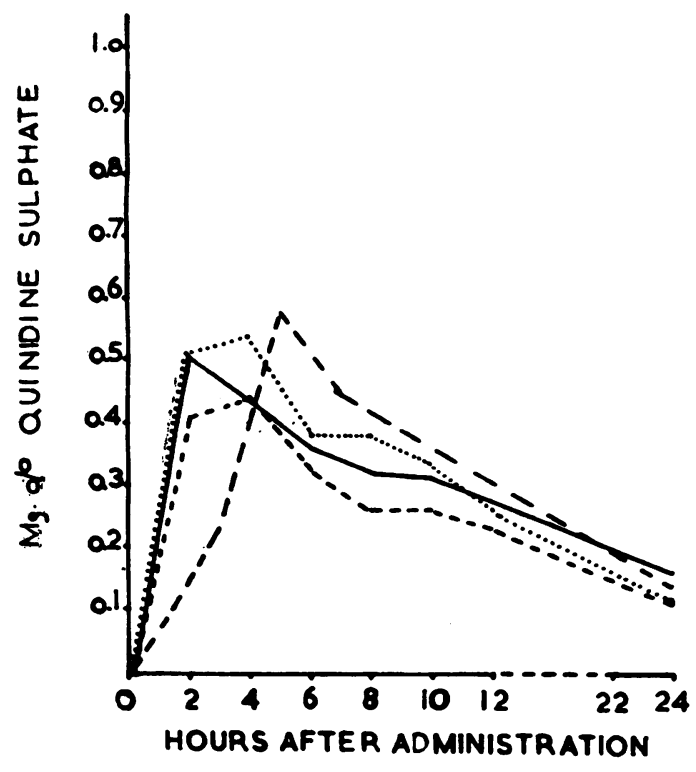

FIG. 1.-Serum levels in four patients after $10 \mathrm{~g}$. of quinidine sulphate.
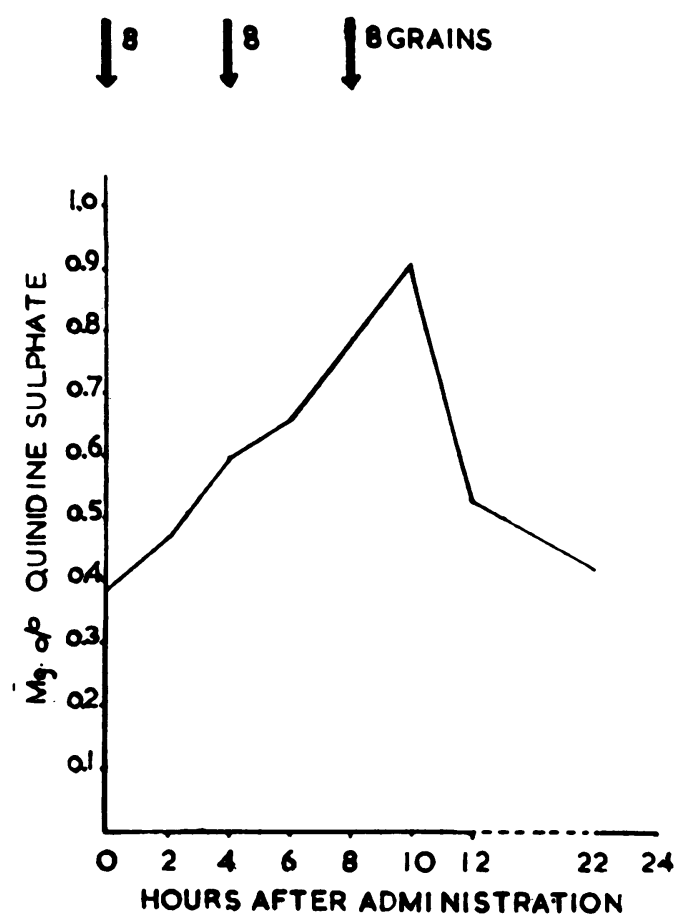

FIG. 2.-Peak serum level is reached two hours after the final dose. The initial level is due to previous day's therapy.

twenty-four hours (Fig. 3). The values in this paper are for quinidine sulphate and represent 80 per cent of the corresponding figures in American reports, in which results are expressed as quinidine base.

The maximum levels found in all cases are shown in Fig. 4. While these generally were higher with larger doses, there was a wide range in different patients having identical amounts. Two factors were possibly responsible for this. One was the variation in the number of days of treatment prior to the day on which the estimations were made, since cumulation occurs (Gold, 1946; Sokolow and Edgar, 1946). The other was the variability in the percentage of quinidine that was excreted in the urine.

As is seen from Fig. 4, most of the therapeutic successes took place at or above the level of 


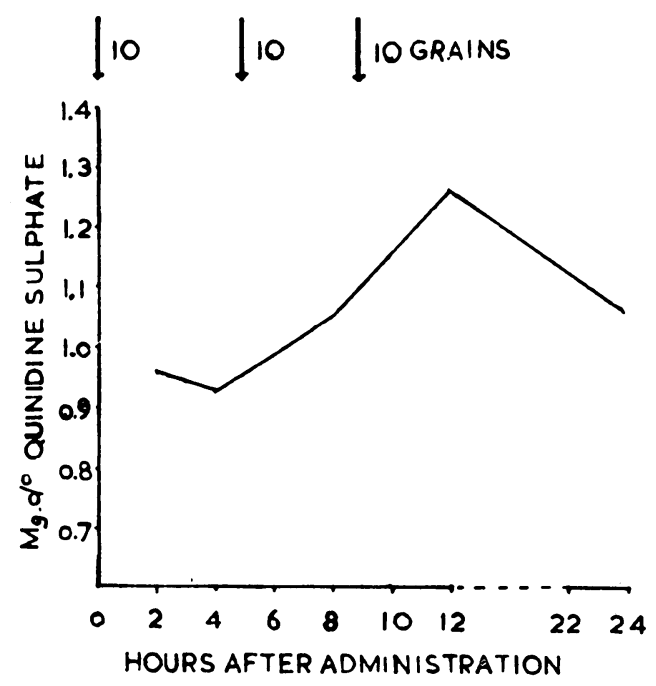

Fig. 3.-Relatively steady serum level in a patient who was on a constant daily dose of quinidine for some months.

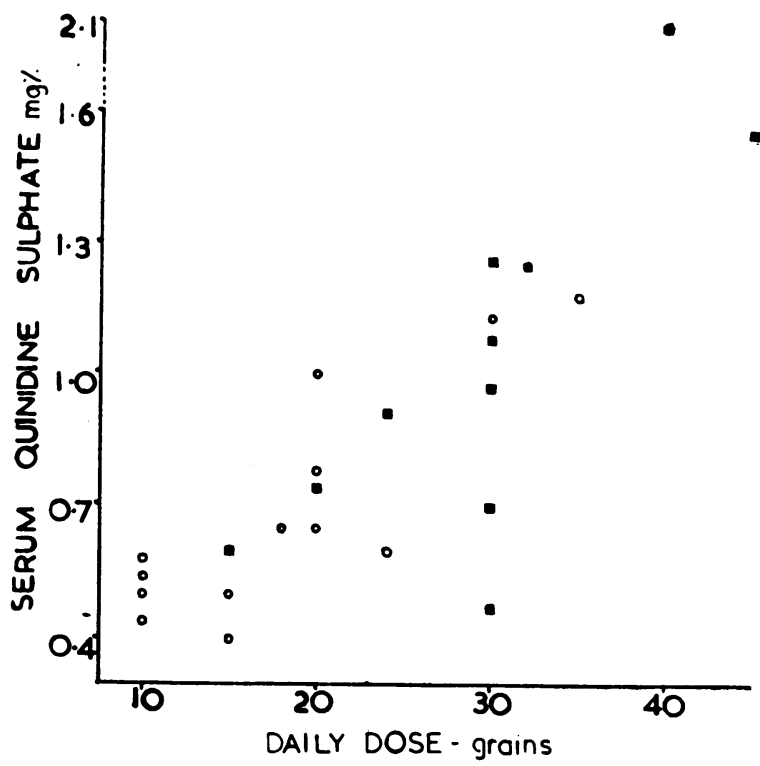

FIG. 4.-Peak levels in all cases in this series, according to dose. The black squares denote reversion to sinus rhythm; and the circles, persistence of arrhythmia.

$0.7 \mathrm{mg} . / 100 \mathrm{ml}$. Conversion to sinus rhythm occurred in 61 per cent of patients with such levels, as compared with 18 per cent of those with lower concentrations. In two cases that failed to respond to daily totals of 20 and 24 grains respectively, the highest serum levels were 0.60 and $0.65 \mathrm{mg}$. These showed that larger doses were safe and worthy of trial. Sinus rhythm was restored in both cases with a daily dose of 30 grains, with levels of 0.7 and $1.08 \mathrm{mg}$. respectively. In four other cases that did not respond, serum levels ranging between 1.0 and $2.1 \mathrm{mg} . / 100 \mathrm{ml}$. were considered to contra-indicate any increase in dose in view of the risk of toxicity.

Individual variance in drug tolerance was seen. In four patients there was no evidence of toxicity at levels of $1.13-1.56 \mathrm{mg} . / 100 \mathrm{ml}$., while two others developed cinchonism at 1.08 and $1.18 \mathrm{mg} . / 100 \mathrm{ml}$. The highest level found was $2.1 \mathrm{mg}$., in a patient with hepatic cirrhosis given $45 \mathrm{mg}$. in four hours. He became very nauseated and disorientated.

In seven patients in whom the 24-hour urinary output of quinidine was determined, the excretion varied from 9 to 34 per cent of the amount ingested. This variation bore no relation to the volumes of urine passed. These findings confirm those of Houston and Perry (1950) and Sokolow and Edgar (1946) who recovered fractions ranging from 1 to 30 per cent. It was because of this variability that no useful information is obtained from any attempt to make the Tanret reaction a quantitative test.

The results obtained with the Tanret test are shown in Fig. 5. There is a fair degree of correlation between serum level and precipitate density in the high and low ranges but considerable overlap with levels between 0.4 and $0.7 \mathrm{mg}$. $/ 100 \mathrm{ml}$. In addition to this the test was materially affected when the volume of urine passed was unusually small or great. Samples of $150 \mathrm{ml}$. or less gave dense opacities even when the serum level was $0.4 \mathrm{mg}$. or under, whereas with large volumes (300$600 \mathrm{ml}$.), " trace" or " one plus " precipitates were found even with serum levels of $0.8-1.0 \mathrm{mg}$. In each patient both Tanret opacities and urinary quinidine levels ran parallel to changes in blood concentration (Fig. 6); but opacities and urine levels varied in relation to the blood concentrations found in different patients. 
WITH TANRETS REAGENT

\begin{tabular}{|c|c|c|c|c|c|c|c|c|c|c|c|c|}
\hline \begin{tabular}{l}
$n$ \\
\multirow{2}{0}{} \\
0 \\
0 \\
$\vdots$ \\
1
\end{tabular} & & 0 & $\begin{array}{l}0 \\
0 \\
0 \\
0\end{array}$ & $\begin{array}{l}0 \\
0 \\
0\end{array}$ & a & a & 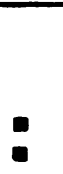 & : & : & a & a & - \\
\hline $\begin{array}{l}u^{n} \\
a \\
w \\
z \\
0\end{array}$ & & 0 & & $\begin{array}{l}a \\
a \\
a\end{array}$ & a & a & & & D & $\begin{array}{l}D \\
D\end{array}$ & & \\
\hline 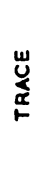 & : & $\begin{array}{l}: \\
:\end{array}$ & $\begin{array}{l}a \\
: \\
0\end{array}$ & : & a & a & & & $D$ & $\Delta$ & & \\
\hline $\overrightarrow{\underline{z}}$ & a & $\begin{array}{l}a \\
\square \\
a\end{array}$ & : & $\begin{array}{l}D \\
D\end{array}$ & & $\nabla$ & & & & & & \\
\hline & $\begin{array}{l}\text { ô } \\
\frac{1}{0} \\
\text { o }\end{array}$ & 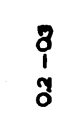 & $\begin{array}{l}\text { t } \\
i \\
y\end{array}$ & $\begin{array}{l}0 \\
1 \\
\text { j }\end{array}$ & $\begin{array}{l}0 \\
\vdots \\
y\end{array}$ & $\begin{array}{l}\hat{0} \\
i \\
\text { ò }\end{array}$ & $\begin{array}{l}9 \\
0 \\
1 \\
0\end{array}$ & $\begin{array}{l}0 \\
1 \\
0 \\
0\end{array}$ & $\begin{array}{l}0 \\
1 \\
8\end{array}$ & $\begin{array}{l}\overline{1} \\
\mathbf{a}\end{array}$ & $\begin{array}{l}\text { บ् } \\
=\end{array}$ & 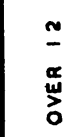 \\
\hline
\end{tabular}

SERUM QUINIDINE (Mg. QUINIDINE SULPHUTE PER $100 \mathrm{~mm}$ )

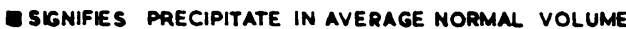

$\nabla$ SIGNIFIES PRECIPITATE IN LARGE VOLUME (350-600 m)

O SIGNIFIES PRECIPITATE IN SMALL VOLUME (45-130 mb)

Fig. 5.-Comparison of serum quinidine levels with density of Tanret precipitates.

TABLE I

INTERPRETATION OF THE TANRET TEST

\begin{tabular}{|c|c|c|c|}
\hline & $\begin{array}{l}\text { Urine volume less than } \\
150 \mathrm{ml} .\end{array}$ & Urine volume $150-350 \mathrm{ml}$. & Urine volume over $350 \mathrm{ml}$. \\
\hline $\begin{array}{c}\text { Tanret } \\
\text { negative }\end{array}$ & $\begin{array}{l}\text { Serum level } \\
\text { under } 0.4 \mathrm{mg} . / 100 \mathrm{ml} \text {. } \\
\text { Increase dose }\end{array}$ & $\begin{array}{l}\text { Serum level } \\
\text { under } 0.4 \mathrm{mg} . / 100 \mathrm{ml} \text {. } \\
\text { Increase dose }\end{array}$ & $\begin{array}{l}\text { Unreliable. } \\
\text { Repeat on different } \\
\text { specimen }\end{array}$ \\
\hline Trace & $\begin{array}{l}\text { Serum level } \\
\text { under } 0.4 \mathrm{mg} . / 100 \mathrm{ml} . \\
\text { Increase dose }\end{array}$ & $\begin{array}{l}\text { Serum level } \\
\text { under } 0.7 \mathrm{mg} . / 100 \mathrm{ml} \text {. } \\
\text { Increase dose if } \\
\text { necessary }\end{array}$ & $\begin{array}{l}\text { Unreliable. } \\
\text { Serum level at } \\
\text { least in therapeutic } \\
\text { range }\end{array}$ \\
\hline One plus & $\begin{array}{l}\text { Unreliable. } \\
\text { Serum level may be } \\
\text { under } 0.4 \mathrm{mg} . / 100 \mathrm{ml} \text {. } \\
\text { Safe to increase dose }\end{array}$ & $\begin{array}{l}\text { Serum level in } \\
\text { therapeutic range. } \\
\text { Safe to increase dose }\end{array}$ & $\begin{array}{l}\text { Serum level high } \\
(0.8 \mathrm{mg} / 100 \mathrm{ml} \text {. or over). } \\
\text { Caution }\end{array}$ \\
\hline Two plus & $\begin{array}{l}\text { Unreliable. } \\
\text { Repeat on different } \\
\text { specimen }\end{array}$ & $\begin{array}{l}\text { Serum level may be high } \\
(0.8-1.0 \mathrm{mg} . / 100 \mathrm{ml} .) \\
\text { Caution }\end{array}$ & $\begin{array}{l}\text { Serum level high. } \\
\text { Caution }\end{array}$ \\
\hline
\end{tabular}




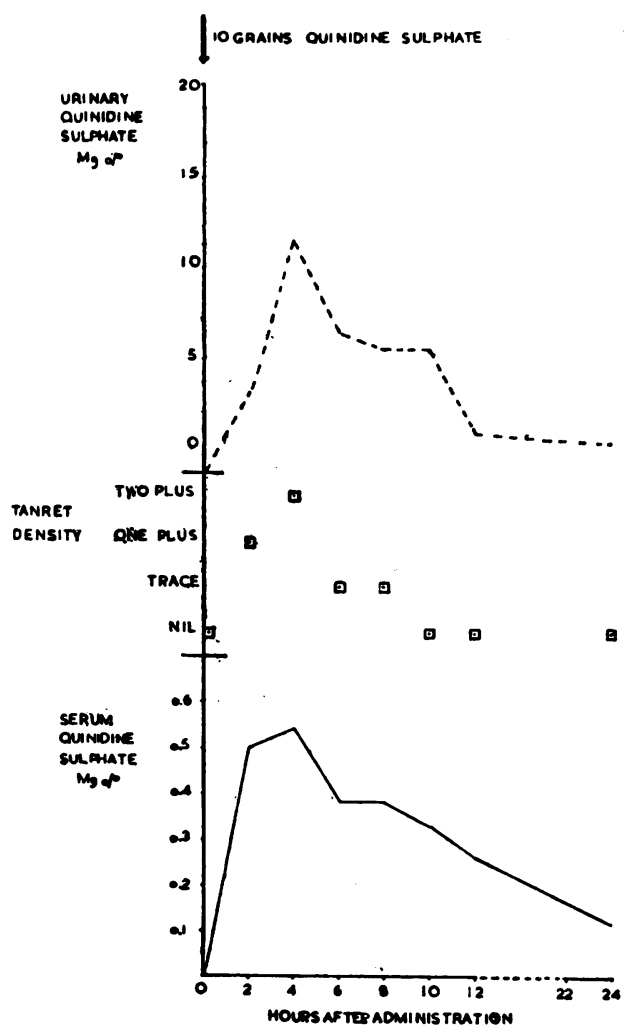

FIG. 6.-Simultaneous serum quinidine levels, Tanret precipitates, and urine quinidine levels in one patient.

\section{Discussion}

These results confirm the findings of American workers concerning the usefulness of serum quinidine determinations for regulation of dosage. Where the desired effect has not been achieved, the serum level indicates whether or not it would be safe or advantageous to increase the dose. Since this method requires special apparatus and laboratory facilities, it was hoped that the Tanret test would furnish an alternative empirical guide. The accuracy of this test is, however, limited by the variability of quinidine excretion, by the influence of sample volume on precipitate density, and by the equivocal results obtained with serum levels of $0.4-0.7 \mathrm{mg} . / 100 \mathrm{ml}$. Provided that these limitations be recognized, however, the test can often give useful information. Table I shows how interpretation of the Tanret test is modified by the volume of the specimen. It will be seen from the Table that the following deductions can be drawn:

(1) With a small volume of urine, only a negative result (or a trace) is significant.

(2) With a large volume, only a definite precipitate is significant.

(3) With intermediate volumes (150-300 ml.), a negative Tanret indicates a serum level below $0.4 \mathrm{mg} . / 100 \mathrm{ml}$., and control of the arrhythmia is unlikely unless the dose be increased. With a trace or " one plus " precipitate the serum level is unlikely to exceed $0.7 \mathrm{mg}$., and the dose may safely be increased if necessary.

(4) The finding of a dense precipitate in a specimen of 200-ml. volume or more indicates a high serum level and caution in dosage is necessary. 
These statements apply not only to decisions concerning the daily total dose, but also to the number of doses to be given on any single day, since the urine can be tested two hours after each dose to ascertain if further doses are advisable. Clearly, any symptoms of intolerance contraindicate further quinidine irrespective of serum level or Tanret test.

Gold (1946) and Sokolow and Edgar (1946) showed that with a fixed daily total, there was cumulation up to 72 hours; after this the serum level did not rise further unless the dose were increased. Hence there is no point in continuing any given dose level for more than this time if there is no response. Similarly if the effective dose does not give rise to toxicity within this time, it may be safely continued (Gold, 1950). These findings were confirmed in the present series.

\section{SUMMARY}

Serum and urinary quinidine levels were estimated by photofluorimetry in 17 patients under treatment for cardiac arrhythmias. The methods are described in detail.

With routine doses, serum levels in the therapeutic range $(0.4-1.0 \mathrm{mg} . / 100 \mathrm{ml}$.) were attained.

The urine of subjects taking quinidine gives a positive Tanret reaction. This test was used as a guide to regulation of dosage.

We are indebted to Dr. Graham Hayward, at whose suggestion the study was undertaken, for advice and criticism. The patients were under the care of the Physicians to the National Heart Hospital.

\section{REFERENCES}

Brodie, B. B., and Udenfriend, S. (1945). J. biol. Chem., 158, 705. (1943). J. Pharmacol., 78, 154.

Delevett, A. F., and Poindexter, A. (1946). Amer. Heart J., 32, 697.

Edgar, A. L., and Sokolow, M. (1950). J. Lab. Clin. Med., 36, 478.

Gold, H. (1946). J. Amer. med. Ass., 132, 547. (1950). In Quinidine in Disorders of the Heart. Hoeber, New York.

Houston, A. B., and Perry, W. F. (1950). Canad. med. Ass. J., 63, 56.

Howie, J. W., and Murray-Lyon, R. M. (1943). Lancet, 2, 317.

Kalmanson, R. W., and Sampson, J. J. (1949). Amer. J. Med., 6, 393.

Lipkin, I. J., and Ramsden, W. (1918). Brit. med. J., 1, 560.

Lothian, G. F. (1942). J. Soc. Chem. Ind., 61, 58.

Martindale's Extra Pharmacopeia. 2nd ed, 1935.

Sokolow, M. (1951). Amer. Heart J., 42, 771.

— and Edgar A. L. (1946). Amer. J. Med., 6, 394. 